\title{
THE ROLE OF SUPERVISORS IN THE SOUTH AFRICAN POLICE SERVICE IN THE SUCCESSFUL UTILISATION OF THE EMPLOYEE ASSISTANCE PROGRAMME
}

\section{Edith de Winnaar, Florinda Taute}

\section{INTRODUCTION}

Murder and suicide are common amongst members of the South African Police Service (SAPS) and supporting statistics to this effect are regularly highlighted in the media (Allers, 2006:2). It is also evident that employee productivity is often influenced negatively as a result of personal and/or work-related problems. McCraty, Atkinson and Tompson (in Williams \& Weyers, 2006:281) mention that particular attention should be given to occupational stress in policing as its potentially negative consequences affect society in more direct and critical ways than in the case of most other organisations. Although the Employee Assistance Programme (EAP) of the SAPS is a suitable vehicle to address these problems, Allers (2006:2) states that, as far as seeking help is concerned, there is a culture amongst police members of "boys don't cry". He continues that there is nearly no internal support for members who are confronted with shocking experiences on a continuous basis. Such a statement seems to imply that referral by supervisors of troubled employees to the EAP is not enough.

The EAP specialises in early identification of troubled employees, intervention to address problems and the re-instatement of employees in the workplace. Supervisors work with employees on a daily basis and they are the first to identify a troubled employee and deal with him/her appropriately. Supervisors know the nature of the work and tasks of the employees, and they can easily identify when an employee's productivity and the quality of his/her work is on the wane.

In practice, it is evident that supervisors in the SAPS are often unable to identify troubled employees early enough and subsequently to refer them to the EAP. It also happens that the supervisor wants to fulfil the role of a social worker in assessing the troubled employee and address his/her problems. When members are eventually referred to the EAP, their problems are already in an advanced state, which complicates the management of the problem and in turn leads to long-term intervention.

This research focused on an investigation into, and a description of, the role, knowledge and attitudes of supervisors in the SAPS, with regard to utilisation of the EAP.

\section{RESEARCH QUESTION}

As the study was qualitative in nature, the following question was formulated, which summarised the objectives of the study and determined the design: what knowledge do SAPS supervisors have and what are their attitudes with regard to their roles in the successful utilisation of the EAP by employees?

\section{THEORETICAL FRAMEWORK}

Tiner (2006:25) indicated that personal problems can and do interfere with a worker's ability to perform on the job. He added that with proper treatment, arranged through an EAP, many troubled employees can be re-instated to a satisfactory level of job performance. Psychological wellbeing and the physical health of employees mean more effective achievement in the 
workplace, increased productivity and better service. In South Africa more organisations are looking after their employees' health by using an EAP.

\section{Benefits of the EAP}

According to Joseph and Injodey (2006:31), the following two benefits are gained from EAPs.

- Support for the employer. Employers want to help their employees to get back to work by recovering quickly from a physical or mental health condition. An EAP provides the organisation with an option to save a good employee and maintain his or her productivity;

- Support for the employee. If stress, distress, substance abuse, or depression take hold, this begins to interfere with an employee's work. Employees would like assistance in order for them to recover quickly from such challenges.

Stoer-Scaggs (1999:37) agrees and states: "Developing an EAP reflects institutional commitment to the human and economic concerns of both individuals and organisations, because it represents an intent to improve quality of life for the entire workforce. This improvement includes enhancing the work performance of individuals and profitability of the sponsoring organisation". It is thus clear that the employer and the employee benefit from the EAP.

\section{The in-house EAP model}

An EAP model is a standard structure, which is used by organisations to provide services to troubled employees in order to address their needs. There are two main models in EAPs, namely internal and external models. The SAPS uses the internal model. According to Cagney (1999:64), EAPs are structured as an internal department of the organisation. The EAP develops links to other parts of the organisation which aid in building one of the EAPs unique strengths. The internal EAPs are positioned to deliver high-quality organisational services and can be more integrated with the organisation than an external vendor can be. The internal EAPs focus is on its core components, but also allows for closer management of EAP professionals.

The EAP in the SAPS consists of three divisions, namely Social Services, Psychological Services and Spiritual Services; collectively they are known as Support Services (HR). The three professions cooperate and collaborate with proactive programmes, namely: prevention of suicide, trauma diffusion, victim empowerment, masifunde ("let us learn") diversity education and interventions at police stations.

According to National Instruction (3/2003:2), the goals of the EAP in the SAPS are:

(a) to assist an employee by promptly identifying and finding solutions to problems that can influence or may influence the employee's performance at work; and

(b) to assist the employee in preventing a further decline in work performance and to reinstate the employee to acceptable levels of work performance.

The SAPS handles the counselling or therapy component. Referrals are usually done in cases where long-term therapy is needed, or when the organisation does not have the appropriate resource, e.g. psychiatrists. Liaison with external resources is maintained to ensure that the employee receives the applicable services as needed.

\section{The role of the supervisor}

The Occupational Health and Safety Act (Act No. 85 of 1993) forces organisations to share responsibility with regard to the health and wellbeing of employees. Employers are also cautious with regard to any legal steps that could be taken against them in terms of the 
abovementioned act, but also in terms of the Basic Conditions of Employment Act (Act No. 75 of 1997) and the Labour Relations Act (Act No. 66 of 1995). Christie (2004:24) stated that business is about growth and profitability. Achieving these results requires productivity, sustainability and goal alignment, which necessitate the maintenance of human resources, which in turn requires preserving workers' health and safety. The author also feels that preserving workers' health and safety means addressing both their physical and mental needs. This implies that employers acknowledge that healthy employees are more productive and they contribute better towards achieving the goals of the organisation.

\section{- Identifying the troubled employees}

According to the standards document of EAPA SA (2005:8) a troubled employee is "an employee suffering from any personal or work-related problem, resulting in a lack of optimal economic and social functioning". Tiner (2006:26) indicated that a supervisor needs to identify changes in work patterns, deterioration in work performance, violations of policy and any issues that compromise the safety of the work environment. Unacceptable work performance is therefore sub-standard performance, or the result of a decline in quality of work. Behaviour that disrupts normal work functions and the work environment is also unacceptable. A troubled employee is therefore an employee who allows personal and/or work-related problems to negatively influence their performance at work.

\section{- Documentation}

A supervisor should, according to Tiner (2006:26), provide written, factual, objective and confidential information that focuses only on job performance. Before a supervisor confronts a troubled employee regarding his/her behaviour, all the facts must be documented (Fourie \& Retief, 2000:39; ICAS, [sa]:8).

\section{- Confrontation}

Cagney (2006:18) reiterates that the supervisor is in a good position to identify employee problems through noticing deterioration in work performance, confront the employee, break through the denial, and use the employment contract as leverage to encourage the employee to take action. When a supervisor confronts an employee, this takes place in three interviews, namely a corrective interview, a warning interview and a final confrontation (Mamasela, 1999:3-4; Fourie \& Retief, 2000:48-49).

\section{- Referral}

Supervisors must have knowledge of the types of referrals that can be made. The following types of referral are discussed by Cagney (2006:19-20):

Informal/self-referral: These are initiated by employees who are aware of a problem or are experiencing enough discomfort to seek resources. They may have been encouraged to use the EAP by co-workers, family members or supervisors;

Formal/management referral: These are directly related to job performance and must be seen as another tool or option for the employee to use in improving job performance.

\section{RESEARCH METHODOLOGY}

The goal of the study was to explore the knowledge and attitudes of supervisors in the SAPS, Western Cape, concerning their roles in the successful utilisation of the Employee Assistance Programme by employees. An applied qualitative approach was used. Semi-structured interviews were used for data collection (Greeff, 2005:296; McLaughlin, 2007:39) and as Bless 
and Higson-Smith (2000:107) pointed out, very helpful in exploratory research. To analyse and interpret the information, Creswell's analytical process was used (De Vos, 2005:334-339).

The pre-investigation consisted of a literature study and consultations with experts. For the purpose of this research, the population was the 500 supervisors of the SAPS in the Western Cape. Supervisors in the SAPS hold different ranks. To ensure representation of every rank, a stratified random sampling method was used (Strydom, 2005:200) in order to divide the population into a number of strata which represented each rank. The strata consisted of inspectors, captains, superintendents and senior superintendents. From each stratum the sampling was done on a random basis. From each rank $2 \%$ were selected for the sample, namely three inspectors, four captains, two superintendents and one senior superintendent, representing black, white and coloured supervisors. The languages represented during the empirical study, were Afrikaans, English and Xhosa. Periods of service ranged from 12 to 27 years and the ages were between 31 and 47 years. In total, the sample consisted of ten supervisors.

\section{ETHICAL ISSUES}

The necessary informed consent was obtained from the participants. The respondents granted permission after they had been informed about the nature of the study and that the interviews would be recorded. The collected data were handled confidentially, anonymously and sensitively, so that the respondents in no way could be identified or be compromised (Strydom, 2002:64-73; McLaughlin, 2007:58-70).

\section{RESEARCH RESULTS}

Themes and sub-themes that were identified can be presented schematically as follows:

\begin{tabular}{|c|c|}
\hline Theme & Sub-themes \\
\hline \multirow[t]{2}{*}{$\begin{array}{l}\text { 1. Knowledge of the SAPS supervisors } \\
\text { concerning the EAP }\end{array}$} & $\begin{array}{l}\text { 1. Assistance to police officers, } \\
\text { supervisors and management }\end{array}$ \\
\hline & 2. Reactive services provided \\
\hline \multirow[t]{5}{*}{$\begin{array}{l}\text { 2. Knowledge of the SAPS supervisors } \\
\text { concerning their roles in the EAP }\end{array}$} & $\begin{array}{l}\text { 1. Liaison between the EAP and the } \\
\text { employees }\end{array}$ \\
\hline & 2. Identifying troubled employees \\
\hline & $\begin{array}{l}\text { 3. Documenting problematic behaviour } \\
\text { and work performance }\end{array}$ \\
\hline & 4. Confrontation of troubled employees \\
\hline & $\begin{array}{l}\text { 5. Referral of troubled employees to } \\
\text { the EAP }\end{array}$ \\
\hline $\begin{array}{l}\text { 3. Attitudes of the SAPS supervisors } \\
\text { concerning the EAP }\end{array}$ & \\
\hline
\end{tabular}

\section{Theme 1: Knowledge of the SAPS supervisors concerning the EAP}

The respondents were not familiar with the concept of an EAP. None of the respondents understood the concept of an EAP or the goals of an EAP, but they understood that employees sometimes experience problems they cannot always manage, and that this has an influence on their daily functioning. The following two sub-themes were identified: 


\section{Sub-theme 1: Assistance to police officers, supervisors and management}

It seems that respondents do not have the necessary knowledge to describe the goals of the EAP. The following responses were efforts to describe the goals.

- “... (t)o help us to cope with trauma. People we can open ourselves up to and we can ask them for help..."

- "... social and psychological help ..."

- "...support to the employee by the employer..."

- “...assistance to police officers in times of emergencies...and you then help our supervisor/manager or the member who has the problem..."

- "Doubt is whether there are people with ears to listen to your input to the problem that you pick up from the employees"

- “...being a commander, we have to know how can you assist our members, how can you support our members, how can you assist us as commanders as well, because if the commander is not aware what is taking place ... it is not easy for him to translate that information to the members ..."

Maynard (2004:36) indicates that in most organisations poor performance management and remediation are pressing concerns and they do need assistance in this area. EAPA SA (1999:20) indicates that consultation will be provided to supervisors regarding the management and referral of employees with job performance and other behavioural problems.

\section{Sub-theme 2: Reactive services provided}

Respondents agreed that services are provided to employees with regard to personal or workrelated problems. Examples that were given included marital problems, financial problems, family problems, stress, depression and alcohol abuse. Respondents reacted as follows:

- “...(L)ike if I'm depressed or stressed, related to the duties that I'm doing”.

- "I've got domestic problems, which at the end of the day can effect my production in my work situation".

- "Maybe I've got something I cannot cope with, then that is when I need your intervention and your help as well".

Christie (2004:24) is of the opinion that an EAP used to the full advantage is a multifaceted tool, capable of addressing several key business concerns, including crisis management, risk management, safety management and performance management.

\section{Theme 2: Knowledge of the SAPS supervisors concerning their roles in the EAP}

The role of the supervisors can be summarised in short as the identification of troubled employees or behavioural problems, documentation, confrontation and referral. Within this theme, five sub-themes were identified:

\section{Sub-theme 1: Liaison between the EAP and the employee}

Respondents are informed about their responsibilities as far as referrals of troubled employees are concerned. The respondents described their roles as follows:

- "...the bridge between the people who work with and under me and the process of providing help".

- "to act as a go-between and mediator". 
- "... I must be an example to them and they must look up to me, they must feel my shift manager is someone I can look up to and if I have a problem, I must be able to go to him and discuss it with him".

- “... I must by nature of the case be able to give them advice, guidance and then, I don't know if I can take that decision, but if I find it necessary, I must do the necessary referral. I believe that by nature of the case as a result of the fact that I, as a person, have more experience in life, it won't be necessary in all cases to refer the people..."

- “... not try to play psychologist".

- "I won't get involved because, ten-to-one, I will slip up".

According to Le Roux (2004), the role of the supervisor can be regarded as the link between the employee and the EAP. Le Roux (2004) is also of the opinion that the supervisor empowers the EAP. There is, however, concern that the supervisors, from within their frame of reference and experience, would want to advise an employee with regard to personal problems, which would probably cause more damage. Le Roux (2004) confirms that supervisors tend to want to fulfil the roles of social workers. According to Le Roux (2004), the supervisor feels apathetic if he/she cannot help the employee and simply refers the employee to the EAP.

\section{Sub-theme 2: Identification of troubled employees}

Respondents provided the following descriptions of a troubled employee:

- “... (Y)ou will notice when there is a change in his life like the member who is not used to be alone, all of a sudden he is always isolated. Maybe you see that this member has a lot of absenteeism, which you are not used to. If you check on his production level, he doesn't produce as before or if you speak to him, for no reason, he may become aggressive, or although you talk to him, you can see he doesn't listen but he is not that person he used to be".

- "...to see what he was before and what is he like now".

- "He does not do the necessary paperwork, fills it out incomplete and the incident book is not filled in correctly, his pocket notebook is not up to date and he does not pass the charges on to the people".

- “....not just the quality of the employee's work deteriorates, but also his/her relationships at work".

From the excerpts above, it is clear that the supervisors identify troubled employees by noticing a change in normal behaviour of the employee and by noticing a decrease in the quality of the employee's performance (Stoer-Scaggs, 1999:42; Fourie \& Retief, 2000:36-37). Cagney (2006:18) reiterates that the supervisor is in a good position to identify employee problems through spotting deterioration in work performance and confronting the employee, breaking through the denial, and using the employment contract as leverage to encourage the employee to take action.

\section{Sub-theme 3: Documenting problematic behaviour and work performance}

The following response was received:

- "... if the person does not admit it and denies that he has a problem, one must be able to prove it. Then you have to be in agreement with the person that he admits it and that he goes to seek help". 
With this statement the respondent highlighted an important role of a supervisor, namely documenting problematic behaviour (Fourie \& Retief, 2000:39; ICAS, [sa]:8), and the agreement that has to be entered into during the confrontation interviews (Fourie \& Retief, 2000:48).

\section{Sub-theme 4: Confrontation of troubled employees}

The responses indicate that the supervisors are not comfortable with their role to confront employees. The respondents reacted as follows:

- "...to talk to the employee as a brother and father".

- "...will show the deterioration in his/her work".

- "I will first determine if the problem is work-related, e.g. a lack of knowledge or discipline, or if it is of personal nature".

- "I will first afford the employee the opportunity to talk to me of his own accord. If the employee does not approach me to talk to me, I will approach him/her very tactfully".

Vineburgh, Ursano, Gifford, Benedek and Fullerton (2006:16) stress that a sense of "mattering" needs to be conveyed to employees through services such as sending a message stating concern from the top down. The researchers agree that an employee should not be confronted upfront, but that the supervisor must also focus on the employee's strong points and not only highlight the negative aspects. In this way the supervisor acknowledges the employee and he/she may then be more willing to address the problematic behaviour. Consequently, the employee will not be lost and this approach will cultivate respect for the supervisor.

\section{Sub-theme 5: Referral of troubled employees to the EAP}

Respondents agreed that they must identify the problem and refer the employee to the EAP. The responses were as follows:

- "Identify the problem areas. Enter into a discussion with the member and find out what is wrong and refer him for assistance”.

- "...the member must first be known instead of contacting you [i.e. the EAP] directly, because then he will feel that there are things done behind his back and that will cause resistance".

- "...if the employee starts to talk to me about his/her problems, I will acknowledge that and then suggest that he/she goes to the EAP and talk to a professional person".

- "...show a certain direction and then the problem can be managed".

- "...if the supervisor is one that will refer someone to the support service in the first place, other members will resist and not go to the supervisor for help".

- "The person with the problem will be your indication".

- "You either go, or I will commence with a disciplinary hearing".

- "I threaten them with the EAP".

Goetzel and Ozminkowski (2006:28) warn that if senior managers do not fully understand EAPs and if they do not become champions of an integrated approach, it will not take root. Cooper (1988:31-32) had already confirmed this behaviour 20 years ago as a form of resistance from the side of the supervisor. The researchers are of the opinion that a threatening attitude will jeopardise the assistance process, because it reinforces the employee's resistance against receiving help. This contributes further to stigmatisation of the employee and the EAP. 


\section{Theme 3: Attitudes of the SAPS supervisors concerning the EAP}

Respondents feel that, if they cannot help the employee, they will refer him/her to the EAP, because the EAP staff members are trained to do this kind of work. From the responses one can deduce that the respondents have a positive attitude towards the EAP and that there is trust in the EAP. The following were the opinions of the respondents:

- "...you see things which I will not notice. He (the employee) will say he is happy, but there are still problems".

- "...the EAP is like doctors. If you are sick you have to go to the doctor".

- "...was quickly helped, and one could notice that the help really had an influence on the members".

- "I could notice physically that the services were effective for those employees who visited the EAP for assistance".

- "...the proactive programmes are very meaningful and informative".

- "...the proactive programmes are successful because they open your eyes regarding things you thought you knew everything about, but not really".

- "...an employee comes back to work and his behaviour changes".

- “...yes, I trust you".

- "I know there are some things I cannot handle myself and which I need help for".

- "I know I can't handle everything 100\%, I need sometimes someone professional".

- "...because of the fact that I have more trust in you, not only me, but the members self, I will refer someone to you any time".

- "....the EAP is more visible at the stations during station visits and these informal discussions promote a relationship of trust".

The above excerpts emphasise that trust and credibility are central to creating and maintaining open communication (Guiniven, 2005:7).

\section{CONCLUSIONS}

- The concept of an EAP, the services and proactive programmes are unfamiliar to the supervisors and they are sometimes still unwilling to use the services provided by the EAP.

- The wellbeing of employees is very important to the respondents and the majority will not hesitate to refer a troubled employee to the EAP for assistance.

- Some supervisors still tend to want to fulfil the role of a social worker themselves.

- The supervisors are not informed of their roles with regard to the EAP and this may be to the detriment of the troubled employees.

\section{RECOMMENDATIONS}

If the SAPS want to care better for their employees and especially decrease the numbers of murders and suicides, it is necessary:

- to equip supervisors adequately with regard to their roles and responsibilities in the EAP;

- to increase their knowledge of the EAP; and

- to train them to utilise the EAP constructively and continuously. 


\section{REFERENCES}

ALLERS, E. 2006. SAPS het nie stelsel om lede te ondersteun in krisistye nie. Beeld, 5 April:2.

BASIC CONDITIONS OF EMPLOYMENT ACT, 1997 (ACT 75 of 1997). Government Gazette, No. 18491, Pretoria: Government Press.

BLESS, C. \& HIGSON-SMITH, C. 2000. Fundamentals of social research methods, an African perspective. Cape Town: Juta.

CAGNEY, T. 1999. Models of service delivery. In: OHER, J.M. The employee assistance handbook. New York: John Wiley \& Sons, Inc.

CAGNEY, T. 2006. The policy-practice gap. Journal of Employee Assistance, 36(3):18-20.

CHRISTIE, J.P. 2004. Promoting employee resiliency. Journal of Employee Assistance, 34(3):24.

COOPER, M.G. 1988. The stages of supervisor resistance. EAP Digest, 8(1):26-33.

DE VOS, A.S. 2005. Qualitative data analysis and interpretation. In: DE VOS, A.S. (ed), STRYDOM, H., FOUCHÉ, C.B. \& DELPORT, C.S.L. Research at grass roots for the social sciences and human service professions $\left(2^{\text {nd }} e d\right)$. Pretoria: Van Schaik Publishers.

EAPA SA. 1999. Standards for employee assistance programmes in South Africa. Johannesburg: EAPA SA Board.

EAPA SA. 2005. Standards for employee assistance programmes in South Africa. Johannesburg: EAPA SA Board.

FOURIE, C. \& RETIEF, R.T. 2000. EAP. Wes-Kaap: SAPS.

GOETZEL, R \& OZMINKOWSKI, R. 2006. Integrating to improve productivity. Journal of Employee Assistance, 36(4):25-28.

GREEFF, M. 2005. Information collection: interviewing. In: DE VOS, A.S. (ed), STRYDOM, H., FOUCHÉ, C.B. \& DELPORT, C.S.L. Research at grass roots for the social sciences and human service professions $\left(2^{\text {nd }} \mathrm{ed}\right)$. Pretoria: Van Schaik Publishers.

GUINIVEN, J.E. 2005. Making employee communication work. Journal of Employee Assistance, 35(1):7-9.

ICAS. [sa]. Employee wellness programme. The ICAS employee assistance programme managers' booklet. Johannesburg.

JOSEPH, B. \& INJODEY, J.I. 2006. Differing requirements. Journal of Employee Assistance, 36(4):31.

LABOUR RELATIONS ACT, 1995 (ACT NO. 66 of 1995). Government Gazette, No. 16861, Pretoria: Government Press.

LE ROUX, S. 2004. Persoonlike onderhoud. 15 Maart, Bellville.

MAMASELA, S. 1999. Supervisory training. Graaff-Reinet: Graaff-Reinet Academy.

McLAUGHLIN, H. 2007. Understanding social work research. London: Sage Publications. MAYNARD, J. 2004. We have the skills, they have the need! Journal of Employee Assistance, 34(3):36. 
NATIONAL INSTRUCTION 3/2003. Employee Assistance Programme (EAP). Consolidation Notice. 23/2003, October 2003.

OCCUPATIONAL HEALTH AND SAFETY ACT, 1993 (ACT 85 of 1993). Government Gazette, No. 14918, Pretoria: Government Press.

STOER-SCAGGS, L. 1999. Employee assistance programs in higher education. In: OHER, J.M. (ed) The employee assistance handbook. New York: Wiley.

STRYDOM, H. 2002. Ethical aspects of research in the social sciences and human service professions. In: DE VOS, A.S. (ed), STRYDOM, H., FOUCHÉ, C.B. \& DELPORT, C.S.L. Research at grass roots for the social sciences and human service professions (2nd ed). Pretoria: Van Schaik Publishers.

STRYDOM, H. 2005. Sampling and sampling methods. In: DE VOS, A.S. (ed), STRYDOM, H., FOUCHÉ, C.B. \& DELPORT, C.S.L. Research at grassroots for the social sciences and human service professions (2nd ed). Pretoria: Van Schaik Publishers.

TINER, P. 2006. Normalizing supervisory EAP training. Journal of Employee Assistance, 36(3):25-26.

VINEBURGH, N.T., URSANO, R.J., GIFFORD, R.K., BENEDEK, D. \& FULLERTON, C.S. 2006. Disaster preparedness in the 21st century. Journal of employee assistance, 36(4):16.

WILLIAMS, H.M. \& WEYERS, M.L. 2006. Proactive stress management: the nature, effect and implications of the South African Police Service's "Managing Stress Effectively" programme. Social Work/Maatskaplike Werk, 42(3/4):281-298.

Ms Edith de Winnaar, postgraduate student; Dr Florinda M Taute, Senior Lecturer, Department of Social Work and Criminology, University of Pretoria, South Africa. 